\title{
Bodo Philipp · Bernhard Schink \\ Two distinct pathways for anaerobic degradation of aromatic compounds in the denitrifying bacterium Thauera aromatica strain AR-1
}

Received: 30 July 1999 / Accepted: 21 October 1999 / Published online: 3 December 1999

(C) Springer-Verlag 1999

\begin{abstract}
Denitrifying bacteria degrade many different aromatic compounds anaerobically via the well-described benzoyl-CoA pathway. We have shown recently that the denitrifiers Azoarcus anaerobius and Thauera aromatica strain AR-1 use a different pathway for anaerobic degradation of resorcinol (1,3-dihydroxybenzene) and 3,5-dihydroxybenzoate, respectively. Both substrates are converted to hydroxyhydroquinone (1,2,4-trihydroxybenzene). In the membrane fraction of $T$. aromatica strain AR-1 cells grown with 3,5-dihydroxybenzoate, a hydroxyhydroquinone-dehydrogenating activity of $74 \mathrm{nmol} \mathrm{min}^{-1}(\mathrm{mg}$ protein $)^{-1}$ was found. This activity was significantly lower in benzoate-grown cells. Benzoate-grown cells were not induced for degradation of 3,5-dihydroxybenzoate, and cells grown with 3,5-dihydroxybenzoate degraded benzoate only at a very low rate. With a substrate mixture of benzoate plus 3,5-dihydroxybenzoate, the cells showed diauxic growth. Benzoate was degraded first, while complete degradation of 3,5-dihydroxybenzoate occurred only after a long lag phase. The 3,5-dihydroxybenzoate-oxidizing and the hydroxyhydroquinone-dehydrogenating activities were fully induced only during 3,5-dihydroxybenzoate degradation. Synthesis of benzoyl-CoA reductase appeared to be significantly lower in 3,5-dihydroxybenzoate-grown cells as shown by immunoblotting. These results confirm that $T$. aromatica strain AR-1 harbors, in addition to the benzoyl-CoA pathway, a second, mechanistically distinct pathway for anaerobic degradation of aromatic compounds. This pathway is inducible and subject to catabolite repression by benzoate.
\end{abstract}

Key words Thauera aromatica.

3,5-Dihydroxybenzoate · Hydroxyhydroquinone .

Benzoyl-CoA pathway $\cdot$ Catabolite repression

B. Philipp (幽) B. Schink

Fakultät für Biologie,

Universität Konstanz, Fach M654, D-78457 Konstanz, Germany

e-mail: Bodo.Philipp@uni-konstanz.de,

Tel.: +49-7531-883557, Fax: +49-7531-882966
Abbreviations 3,5-DHB: 3,5-Dihydroxybenzoate . $H H Q$ : Hydroxyhydroquinone

\section{Introduction}

Aromatic compounds are widespread in nature and serve many different biological functions. Their most important sources are lignin, aromatic amino acids and secondary metabolites of plants. The number of xenobiotic aromatic substances entering the environment is increasing and is contributing to the existing pool of naturally occurring compunds. Thus, the degradation of aromatic compounds by microorganisms is an essential contribution to the global carbon cycle as well as to the detoxification of wastewater and contaminated soils. Microorganisms use different strategies for complete degradation of these compounds, depending on the availability of $\mathrm{O}_{2}$. Under oxic conditions, $\mathrm{O}_{2}$ serves as an essential cosubstrate for destabilization and cleavage of aromatic compounds in oxygenase reactions (Dagley 1971). In the absence of $\mathrm{O}_{2}$, the aromatic ring is destabilized by a reductive attack (Heider and Fuchs 1997; Schink et al. 1999). The most common and best-studied pathway in anaerobic degradation is the benzoyl-CoA pathway (Harwood et al. 1999) with the key enzyme benzoyl-CoA reductase. This enzyme from the denitrifying bacterium Thauera aromatica strain K-172 has been studied in great detail (Boll and Fuchs 1995; Boll et al. 1997).

Recently, we have shown that the reductive strategy for ring destabilization is not the only one used in anaerobic degradation of aromatic compounds. The denitrifying bacterium Azoarcus anaerobius strain LuFRes1 degrades resorcinol (1,3-dihydroxybenzene) through an entirely different mechanism (Philipp and Schink 1998). Resorcinol is first hydroxylated to hydroxyhydroquinone (HHQ, 1,2,4-trihydroxybenzene) which can be further oxidized to hydroxybenzoquinone, the first nonaromatic intermediate. Both reactions are catalyzed by membrane-bound enzyme activities. Thus, in this case A. anaerobius uses oxidation rather than reduction to overcome the stability of 
the aromatic ring. In addition, we showed that $T$. aromatica strain AR-1 converts also 3,5-dihydroxybenzoate (3,5DHB) to HHQ by hydroxylation and subsequent decarboxylation (Gallus and Schink 1998). The further fate of HHQ in this organism remained unknown.

Here, we report on our work on 3,5-DHB degradation by this $T$. aromatica strain which differs from the type strain K-172 only by its ability to degrade 3,5-DHB (Gallus et al. 1997). We checked for the presence of the HHQdehydrogenating activity and performed comparative physiological studies with cells grown with either 3,5DHB or benzoate in order to assess the presence of a second, mechanistically distinct pathway for anaerobic degradation of aromatic compounds in addition to the welldescribed benzoyl-CoA pathway.

\section{Materials and methods}

Organism and cultivation

Thauera aromatica strain AR-1 was grown at $28^{\circ} \mathrm{C}$ in a nonreduced bicarbonate-buffered mineral medium (Widdel and Pfennig 1981) containing $8 \mathrm{mM} \mathrm{NaNO}{ }_{3}$ as electron acceptor, $1 \mathrm{mM}$ $\mathrm{Na}_{2} \mathrm{SO}_{4}$ as sulfur source, vitamin solution, selenite-tungstate solution (Tschech and Pfennig 1984), and trace element solution SL10 (Widdel et al. 1983). The medium was dispensed anoxically into infusion bottles which were sealed with butyl rubber septa. Substrates (3,5-DHB and benzoate) were added from sterile anoxic stock solutions. The strain was maintained in liquid cultures with 3,5-DHB (2 $\mathrm{mM})$ as substrate.

\section{Growth experiments}

For growth experiments, aliquots of an exponentially growing culture were transferred to an infusion bottle containing fresh medium with the respective carbon and energy source. Media were inoculated with $3 \%(\mathrm{v} / \mathrm{v})$ preculture. Growth was followed by measuring turbidity at $578 \mathrm{~nm}\left(\mathrm{OD}_{578}\right)$ in a Hitachi $100-40$ spectrophotometer. Samples $(1 \mathrm{ml})$ were taken aseptically with syringes: $100 \mu \mathrm{l}$ was preserved immediately for chemical analysis, the residual volume was used for $\mathrm{OD}_{578}$ determination. The method of preservation depended on the individual aromatic substrate. Samples containing benzoate only were added to $400 \mu \mathrm{l}$ phosphoric acid $(100 \mathrm{mM})$, while 3,5-DHB-containing samples were transferred to $400 \mu \mathrm{l}$ ice-cold $\mathrm{H}_{2} \mathrm{O}$ because under acidic conditions 3,5-DHB reacts chemically with nitrite which was present in most samples. Diluted samples were centrifuged at $15,000 \times g$ for $10 \mathrm{~min}$ at $4^{\circ} \mathrm{C}$ and supernatants were stored at the same temperature until HPLC analysis.

\section{Cell suspension experiments}

Cultures were harvested in the middle of the exponential growth phase at an optical density around 0.2 by centrifugation at $6,000 \times g$ for $25 \mathrm{~min}$ at $4{ }^{\circ} \mathrm{C}$ under anoxic conditions in an anaerobic chamber (Coy, Ann Arbor, Mich.). Cells were washed once with anoxic potassium phosphate buffer $(50 \mathrm{mM}, \mathrm{pH} 7.0)$ and resuspended in small amounts of the same buffer (ca. $3 \mathrm{ml}$ for a pellet resulting from 11 of culture). These suspensions were kept on ice and used for experiments within 1-2 h. For degradation experiments, cells were added to $50 \mathrm{mM}$ anoxic potassium phosphate buffer ( $\mathrm{pH} 7.0$ ) containing $4 \mathrm{mM}$ nitrate, to a final optical density of 2.0 [equivalent to ca. $0.7 \mathrm{mg}$ dry weight per ml (Gallus et al. 1997)]. Experiments were performed under nitrogen gas in butyl rubber-sealed Hungate tubes, and reactions were started by addition of the aro- matic substrates. Samples were taken directly after starting the reaction and at regular intervals. Samples were preserved as described above.

\section{Preparation of cell-free extracts}

Cells were grown in 11 infusion bottles starting with $2 \mathrm{mM}$ of substrate. After substrate depletion, another $1 \mathrm{mM}$ of substrate was added. Final optical densities of 0.4-0.7 were reached. Cells were harvested as described above in the late exponential growth phase. Dense cell suspensions were either used immediately for preparation of extracts or quickly frozen in liquid $\mathrm{N}_{2}$ and stored at $-20^{\circ} \mathrm{C}$. Dense cell suspensions were passed anoxically two times through a French press at $138 \mathrm{MPa}$. The crude extract was separated from cell debris by centrifugation at $20,000 \times g$ for $20 \mathrm{~min}$ at $4^{\circ} \mathrm{C}$. Fractionation of the cell-free extract was obtained by centrifugation at $100,000 \times g$ and $4^{\circ} \mathrm{C}$ for $1 \mathrm{~h}$ in a Beckman TL ultracentrifuge (Beckman Instruments, München, Germany). The membrane fraction was resuspended with anoxic potassium phosphate buffer (50 mM, pH 7.0) in a volume equal to that of the cytosolic fraction.

Protein determination was carried out by the method of Bradford (1976).

\section{Determination of enzyme activities}

All measurements of enzyme activities were performed under strictly anoxic conditions at $30^{\circ} \mathrm{C}$ in $5 \mathrm{ml}$ Hungate tubes or $1.5 \mathrm{ml}$ cuvettes using anoxic buffers and solutions. Tubes and cuvettes were flushed with $\mathrm{N}_{2}$ and closed with butyl septa. All additions and samplings were done with gas-tight Unimetrix microliter syringes (Macherey-Nagel, Düren, Germany). Linear correlation of protein amount and reaction rates were checked for in all assays.

HHQ-dehydrogenating activity catalyzes the conversion of HHQ to hydroxybenzoquinone with the concomitant reduction of nitrate to nitrite and was measured as described (Philipp and Schink 1998).

3,5-DHB oxidizing activity catalyzes the hydroxylation of 3,5-DHB to 2,3,5-trihydroxybenzoate and is localized in the membrane fraction (Gallus and Schink 1998). It was measured with $\mathrm{K}_{3} \mathrm{Fe}(\mathrm{CN})_{6}$ as electron acceptor in a photometric assay following the reduction of $\mathrm{K}_{3} \mathrm{Fe}(\mathrm{CN})_{6}$ at $420 \mathrm{~nm}\left(\varepsilon_{420 \mathrm{~nm}}\right.$ of $\mathrm{K}_{3} \mathrm{Fe}(\mathrm{CN})_{6}=$ $\left.0.9 \mathrm{mM}^{-1} \mathrm{~cm}^{-1}\right)$. An assay mixture contained $50 \mathrm{mM}$ Tris/ $\mathrm{HCl}$ ( $\mathrm{pH} 8.0$ ), membrane fraction or cell-free extract (ca. $1.0 \mathrm{mg}$ protein) and $1 \mathrm{mM} \mathrm{K}_{3} \mathrm{Fe}(\mathrm{CN})_{6}$, and was started by addition of $1 \mathrm{mM}$ 3,5-DHB. The reaction product 2,3,5-trihydroxybenzoate is decarboxylated to HHQ by a soluble enzyme (Gallus and Schink 1998). Thus, 3,5-DHB was converted to HHQ without accumulation of the trihydroxybenzoate when unfractionated cell-free extracts were used for the assay. The rate of 3,5-DHB oxidation was calculated from the $\mathrm{K}_{3} \mathrm{Fe}(\mathrm{CN})_{6}$ reduction rate based on a 2:1 stoichiometry of electron acceptor to electron donor.

Benzoyl-CoA reductase was measured as described (Heider et al. 1998).

\section{SDS-PAGE and immunoblotting}

SDS-PAGE was carried out according to Laemmli (1970) using gels containing $10 \%$ acrylamide. For immunoblot analysis of benzoyl-CoA reductase (Heider et al. 1998), cell-free extracts were separated on SDS gels and subsequently transferred on nitrocellulose filters (Schleicher \& Schüll, Dassel, Germany) with a Multiphor system (Pharmacia, Freiburg, Germany). Benzoyl-CoA reductase was detected immunologically by luminescence using the ECL system (Amersham).

\section{HLPC analysis}

HPLC analysis was performed as described (Philipp and Schink 1998). For separation of 3,5-DHB and benzoate, an eluent mixture 
Table 1 Hydroxyhydroquinone-dehydrogenating activity in cellfree extract fractions of Thauera aromatica strain AR-1 after ultracentrifugation $(100,000 \times g, 1 \mathrm{~h})$; in vivo activity of $T$. aromatica strain AR-1 for degradation of 3,5-dihydroxybenzoate: $22.6 \mathrm{nmol}$ $\min ^{-1}(\mathrm{mg} \text { protein })^{-1}$ (Gallus et al. 1997). Percentages in parentheses indicate yields

\begin{tabular}{llrr}
\hline Preparation & $\begin{array}{l}\text { Protein amount } \\
(\mathrm{mg})\end{array}$ & $\begin{array}{l}\text { Specific activity } \\
{\left[\mathrm{nmol} \mathrm{min}^{-1}\left(\mathrm{mg} \mathrm{protein}^{-1}\right]\right.}\end{array}$ & $\begin{array}{l}\text { Total activity } \\
\left.(\mathrm{nmol} \mathrm{min})^{-1}\right)\end{array}$ \\
\hline Cell-free extract & 3.5 & 12.8 & $148 \quad(100 \%)$ \\
Cytosolic fraction & 2.9 & 4.6 & $42.7 \quad(28.9 \%)$ \\
Membrane fraction & 0.5 & 74.1 & $91.3 \quad(61.7 \%)$ \\
Membrane fraction of benzoate-grown cells & 0.5 & 4.2 & - \\
\hline
\end{tabular}

of $50 \%$ ammonium acetate buffer (100 mM, pH 2.6) and $50 \%$ methanol was employed.

Chemicals

${ }^{14} \mathrm{C}$-ring labeled benzoyl-CoA and the antiserum against benzoylCoA reductase were kindly provided by G. Fuchs (Freiburg). All other chemicals and gases were of analytical grade and highest purity available.

\section{Results}

HHQ-dehydrogenating activity

Thauera aromatica strain AR-1 transforms 3,5-DHB to HHQ (Gallus and Schink 1998). To investigate the further fate of HHQ, we checked for the HHQ-dehydrogenating activity described for Azoarcus anaerobius (Philipp and Schink 1998). HHQ-dehydrogenating activity was also measured in cell extracts of 3,5-DHB grown cells of $T$. aromatica strain AR-1 (Table 1). Nitrate was used as electron acceptor and hydroxybenzoquinone was identified as the oxidation product by HPLC analysis. The activity was six-fold enriched in the membrane fraction. In the membrane fraction of cells grown with benzoate, this activity was 18 -fold lower. We also checked for 3,5-DHB oxidizing activity as the initial reaction of the proposed degradation pathway in benzoate-grown cells using $\mathrm{K}_{3} \mathrm{Fe}(\mathrm{CN})_{6}$ as electron acceptor. In the membrane fraction of these cells, we found very low 3,5-DHB-oxidizing activity [0.6

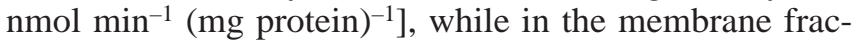
tion of 3,5-DHB-grown cells we measured an activity of

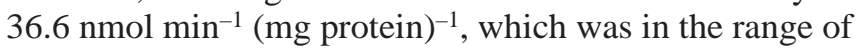
data published earlier (Gallus and Schink 1998).

Degradation studies with cell suspensions

In order to test whether benzoate-grown cells of T. aromatica strain AR-1 are induced for 3,5-DHB metabolism and whether 3,5-DHB grown cells can degrade benzoate, we performed degradation studies with cell suspensions. Benzoate-grown cells did not degrade 3,5-DHB (Fig. 1A). Induction of 3,5-DHB degradation after 3-6 h was observed in only less than $20 \%$ of the experiments. Cells grown with 3,5-DHB consumed benzoate at a very low rate (Fig. 1B). A full induction of benzoate degradation was not observed. The respective growth substrates were
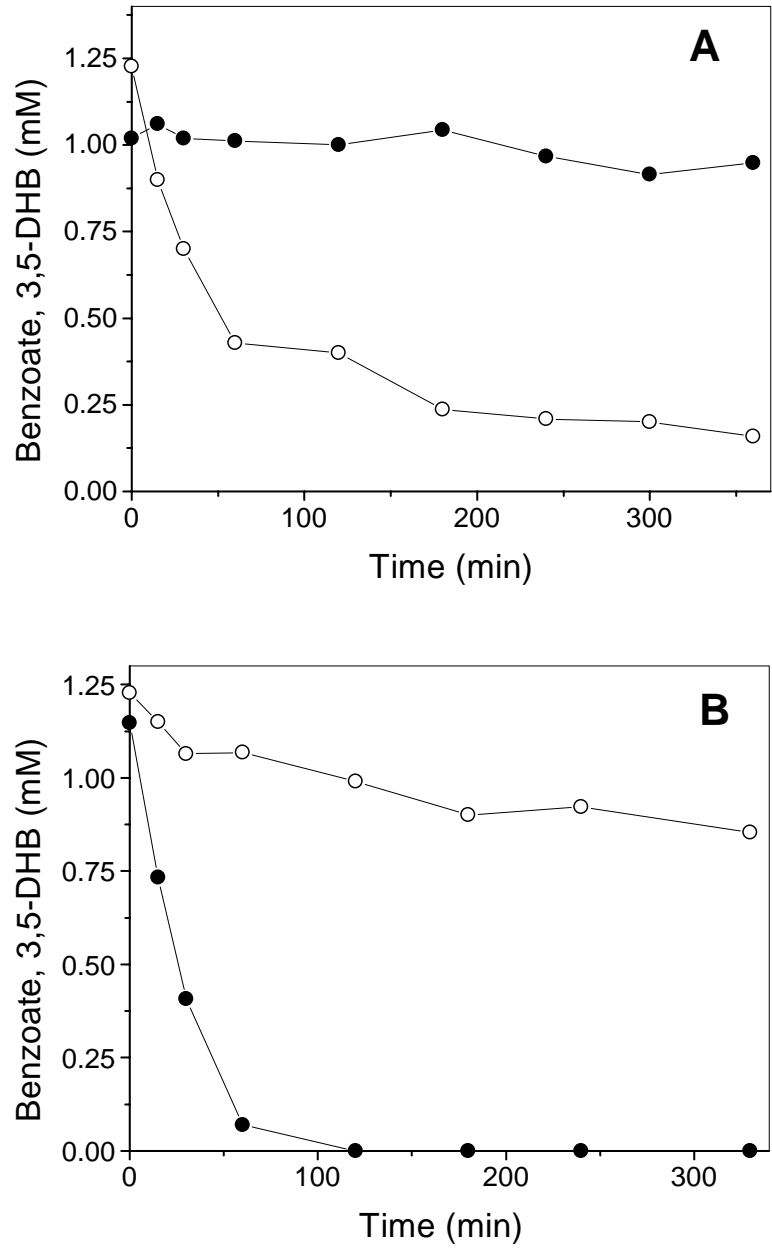

Fig. 1A,B Degradation of 3,5-dihydroxybenzoate (O) and benzoate $(O)$ by cell suspensions of Thauera aromatica strain AR-1. A Benzoate-grown cells B 3,5-dihydroxybenzoate-grown cells

degraded at high rates indicating that the bacteria were in stable physiological condition (Fig. 1A,B).

\section{Growth experiments}

Benzoate-grown cells were transferred to a medium with 3,5-DHB as growth substrate, and 3,5-DHB-grown cells to a benzoate-containing medium. During incubation, no significant lag phases were observed in both cases. The cells commenced to grow with the respective other substrate as fast as with their original growth substrate (not 


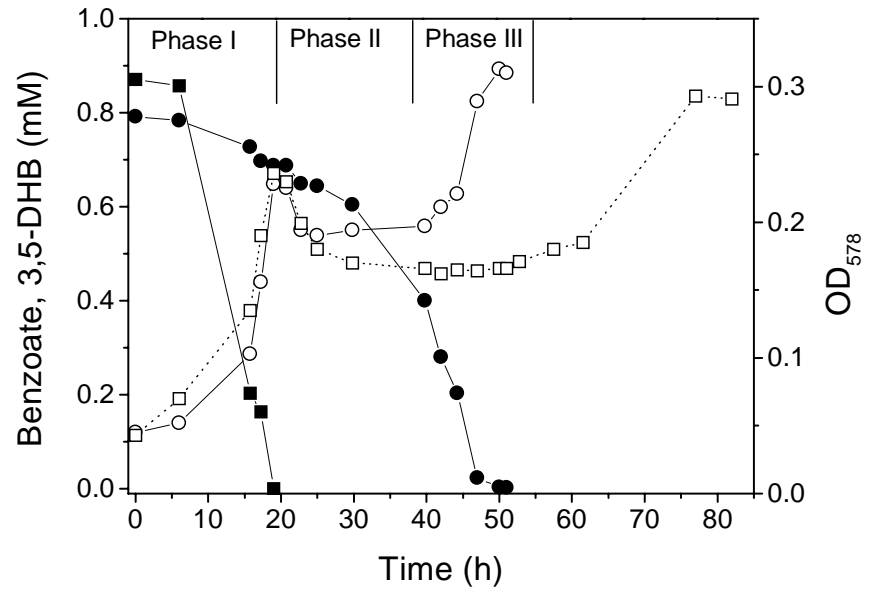

Fig. 2 Diauxic growth of Thauera aromatica strain AR-1 with a mixture of 3,5-dihydroxybenzoate and benzoate showing optical densities (open symbols). Precultures were grown with either 3,5dihydroxybenzoate $(\bigcirc)$ or benzoate $(\square)$. Degradation of 3,5-dihydroxybenzoate (O) and benzoate ( $\boldsymbol{\square})$ and indication of the three characteristic growth phases refer only to the culture inoculated with 3,5-dihydroxybenzoate-grown cells

shown). When cells were transferred to a medium containing a mixture of benzoate and 3,5-DHB, growth was biphasic (Fig. 2). The cultures started to grow without a lag phase. Growth ceased after about $20 \mathrm{~h}$, and the optical density decreased slightly. After a lag phase, the bacteria started to grow again and reached a stable stationary phase. This lag phase after the first exponential phase was longer when the preculture was grown with benzoate. Cultures inoculated with 3,5-DHB grown cells started the second exponential phase after about $40 \mathrm{~h}$, while those inoculated with benzoate-grown cells reached this phase after $60 \mathrm{~h}$ (Fig. 2).

In these experiments, benzoate was always degraded first (Fig. 2) and benzoate degradation correlated with growth in the first exponential phase (phase I). 3,5-DHB was consumed during phase I and the long lag phase (phase II) only at a low rate. This rate increased significantly when the second exponential phase (phase III) started. After 3,5-DHB was consumed completely, growth stopped. This order of substrate utilization was independent of the growth substrate in the preculture.

Activity levels of 3,5-DHB-degrading enzymes during diauxic growth

Activity levels of enzymes involved in degradation of 3,5DHB were checked in the three phases of diauxic growth. The growth of three parallel cultures with benzoate plus 3,5-DHB as substrates was followed and cells were harvested in the three characteristic growth phases, indicated in Fig. 2. From these cultures, cell-free extracts were prepared and the 3,5-DHB oxidizing and the HHQ-dehydrogenating activity were determined (Fig. 3). Both activities were significantly higher in phase III than in phases I and II. The 3,5-DHB-oxidizing activity was increased four- to

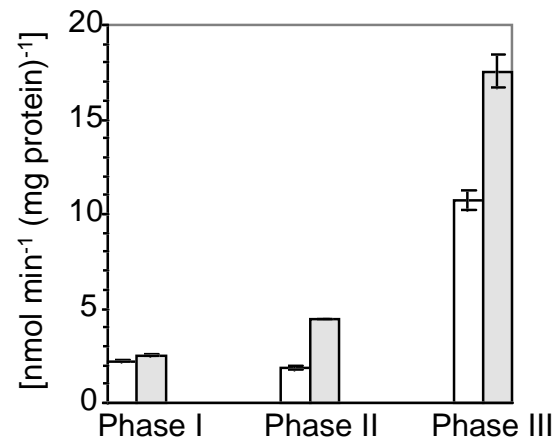

Fig. 3 Specific activities of the 3,5-dihydroxybenzoate-oxidizing (gray bars) and the hydroxyhydroquinone-dehydrogenating activity (white bars) in cell-free extracts during diauxic growth of Thauera aromatica strain AR-1 with benzoate and 3,5-dihydroxybenzoate. The different phases correspond to the growth phases indicated in Fig. 2

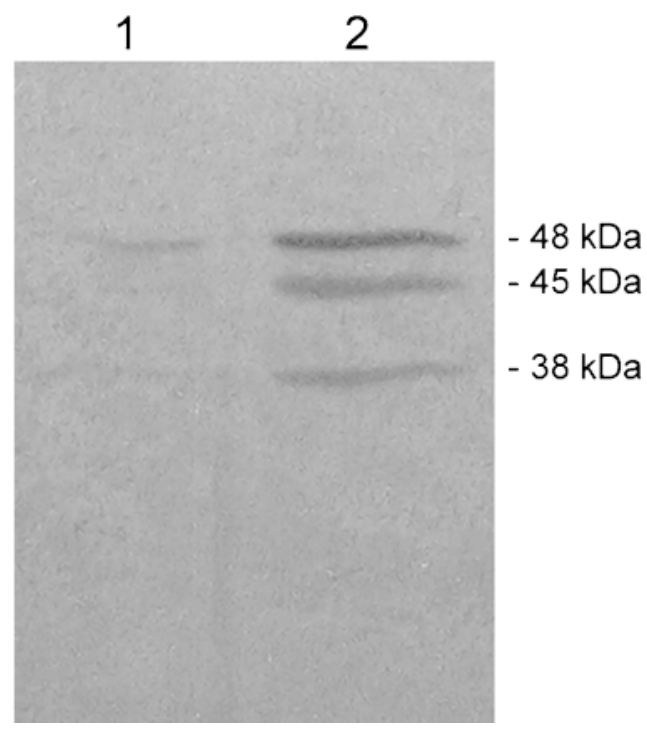

Fig. 4 Immunoblot for detection of benzoyl-CoA reductase in cell-free extracts of Thauera aromatica strain AR-1 with antisera against the enzyme of $T$. aromatica strain K-172. Lane 1 Extract from 3,5-dihydroxybenzoate-grown cells; lane 2 extract from benzoate-grown cells. The molecular masses indicate the masses of the three larger subunits of benzoyl-CoA reductase; the smallest subunit $(32 \mathrm{kDa})$ does not react with the antiserum (D. Laempe, personal communication)

eight-fold, and the HHQ-dehydrogenating activity ca. five-fold. In both cases, activities in phase III reached values typical of 3,5-DHB-grown cells.

\section{Induction of benzoyl-CoA-reductase}

Activity of the benzoyl-CoA reductase was checked in cell extracts of benzoate- and 3,5-DHB-grown cells. Unfortunately, we failed to detect the activity of this enzyme in strain AR-1, although many attempts under various conditions were made. However, an immunoblot analysis was possible because antibodies raised against benzoylCoA-reductase of the $T$. aromatica type strain K-172 
cross-reacted with the enzyme of strain AR-1. The enzyme was detectable in cell-free extracts of benzoategrown cells, while in 3,5-DHB grown cells the amount of enzyme was significantly lower (Fig. 4). Furthermore, the protein patterns of the extracts as analyzed by SDS-PAGE were significantly different (not shown).

\section{Discussion}

Anaerobic degradation of 3,5-DHB by Thauera aromatica strain AR-1 was shown to proceed via a novel pathway by conversion of 3,5-DHB to HHQ (Gallus and Schink 1998). In the study presented here, we found a HHQ-dehydrogenating activity converting HHQ to hydroxybenzoquinone in the membrane fraction of this strain. The specific activity was in the range of the in vivo activity of T. aromatica strain AR-1. Recently, membranebound HHQ-dehydrogenating activity was shown to be the dearomatizing step in resorcinol degradation by Azoarcus anaerobius (Philipp and Schink 1998). Thus, the novel concept for anaerobic degradation of aromatic compounds found in A. anaerobius could be extended to the degradation of a different substrate and to a further denitrifying bacterium. According to this concept, phenolic compounds with their hydroxyl groups in meta position to each other are hydroxylated by membrane-bound enzymes yielding HHQ, which is later dehydrogenated to hydroxybenzoquinone. The further fate of hydroxybenzoquinone as the first nonaromatic intermediate has not yet been elucidated in detail; in cell-free extracts of A. anaerobius, we found conversion of hydroxybenzoquinone to several compounds of which two were identified as acetate and succinate (Philipp 1999). A similar conversion was observed in cell-free extracts of $T$. aromatica strain AR-1. It remains to be elucidated whether more phenolic compounds are metabolized by denitrifying bacteria via this oxidative pathway.

Apparently, T. aromatica strain AR-1 harbors two mechanistically distinct pathways for anaerobic degradation of aromatic compounds, the new oxidative pathway and the well-described benzoyl-CoA pathway (Fig. 5). Our physiological studies with 3,5-DHB-grown cells and with benzoate-grown cells confirmed the presence of these two different pathways. Benzoate-grown cells were not induced for 3,5-DHB degradation, and the 3,5-DHBoxidizing and HHQ-dehydrogenating enzymatic activities were only barely detectable in extracts of these cells. Similar results were obtained for resorcinol degradation by $A$. anaerobius (Philipp and Schink 1998). 3,5-DHB-grown cells were only weakly induced for benzoate metabolism, and expression of benzoyl-CoA reductase was significantly lower in these cells, as shown by immunoblotting. With a mixture of benzoate and 3,5-DHB, T. aromatica strain AR-1 showed diauxic growth. Benzoate was consumed as the preferred substrate while 3,5-DHB degradation occurred at a high rate only after a considerable lag phase. Apparently, T. aromatica shifts between the two pathways, as reflected by the activity levels of the respec-<smiles>CC(Cc1c(O)cc(C(=O)[O-])cc1O)C(C)(O)C(C)(C)C</smiles><smiles>O=C([O-])c1ccccc1</smiles><smiles>CC(C(=O)O)c1c(O)cc(C(=O)[O-])c(O)c1O</smiles><smiles>CC(C)c1c(O)ccc(O)c1O</smiles><smiles>[14CH]=[14CH]C1=C(O)C(=O)C=CC1=O</smiles>

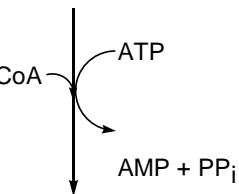<smiles>O=C(O)c1ccccc1</smiles>

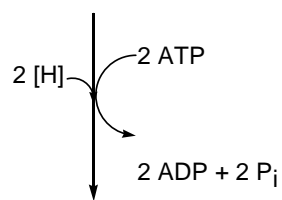<smiles>O=C(O)OCC(=O)OCc1ccccc1</smiles><smiles>CCC(C)OCCO</smiles>

Fig. 5 Initial reactions in the anaerobic degradation of 3,5-dihydroxybenzoate and benzoate by Thauera aromatica strain AR-1

tive enzymes initiating 3,5-DHB degradation. The coincidence of enzyme induction with the usage of 3,5-DHB for growth is an additional confirmation of the physiological relevance of the novel oxidative reactions. The intermediary repression of growth might be due to toxic effects of nitrite, which accumulated during benzoate degradation, as well as to possible further stress effects. For example, it was described that Escherichia coli turns on its general stress response system during diauxic shift from glucose to lactose (Fischer et al. 1998).

Our results allow some conclusions on the regulation of these two pathways. Previous studies on the regulation of anaerobic degradation of aromatic compounds in $T$. aromatica $\mathrm{K}-172$ revealed that the synthesis of enzymes necessary for degrading compounds via the benzoyl-CoA pathway is induced by the respective substrates (Dangel et al. 1991; Heider et al. 1998). Synthesis of the enzymes initiating 3,5-DHB-degradation appears to be strictly regulated by an induction mechanism as well. They are synthesized only in the presence of the substrate; perhaps, 3,5-DHB itself acts as the inducer. In addition, 3,5-DHBmetabolism is subject to catabolite repression, which ap- 
pears to be mediated by the presence of benzoate as substrate. The degradation of benzoate through the benzoylCoA pathway may repress the expression of genes necessary for the breakdown of 3,5-DHB even in the presence of the possible inducer. This additional level of regulation results in sequential degradation of benzoate and 3,5DHB. However, the temporal pattern of diauxic growth varied, depending on the growth substrate of the preculture. Cultures inoculated with benzoate-grown cells showed a significantly longer intermediary lag phase. This indicates that in these cells the induction of 3,5-DHB metabolism is impeded, compared to cells which were pregrown with 3,5-DHB.

It remains unknown by which cellular mechanism catabolite repression is mediated in $T$. aromatica strain AR-1. Concerning sugars, cAMP is the decisive signaling molecule in gram-negative bacteria (Postma et al. 1993), while in gram-positive bacteria other mechanisms are employed (Hueck and Hillen 1995). The phenomena of diauxic growth and catabolite repression in anaerobic metabolism of aromatic compounds have not yet been described. In general, not much is known about the molecular mechanisms which regulate anaerobic degradation of aromatic compounds.

For detailed studies on the regulation in $T$. aromatica AR-1, we need to know more about the novel oxidative pathway for anaerobic degradation of aromatic compounds in denitrifying bacteria. The complete elucidation of this new pathway and the isolation of its key enzymes and genes are priority subjects and are currently being investigated.

Acknowledgements The authors are indebted to D. Laempe and G. Fuchs (University of Freiburg, Germany) for the generous gift of ${ }^{14} \mathrm{C}$-labeled benzoyl-CoA and antibodies against benzoyl-CoA reductase as well as for their kind support in some experiments. This study was supported by the Deutsche Forschungsgemeinschaft through its special research program, Biochemistry of Anaerobic Bacteria.

\section{References}

Boll M, Fuchs G (1995) Benzoyl-CoA reductase (dearomatizing), a key enzyme of anaerobic aromatic metabolism. ATP dependence of the reaction, purification and some properties of the enzyme from Thauera aromatica strain K172. Eur J Biochem 234:921-933

Boll M, Albracht SSP, Fuchs G (1997) Benzoyl-CoA reductase (dearomatizing), a key enzyme of anaerobic aromatic metabolism. A study of adenosine-triphosphatase activity, ATP stoichiometry of the reaction and EPR properties of the enzyme. Eur J Biochem 244:840-851

Bradford MM (1976) A rapid sensitive method for the quantification of microgram quantities of protein utilizing the principle of protein-dye binding. Anal Biochem 72:248-254
Dagley S (1971) Catabolism of aromatic compounds by micro-organisms. Adv Microb Physiol 6:1-46

Dangel W, Brackmann R, Lack A, Mohamed M, Koch J, Oswald B, Seyfried B, Tschech A, Fuchs G (1991) Differential expression of enzyme activities initiating anoxic metabolism of various aromatic compounds via benzoyl-CoA. Arch Microbiol 155:256-262

Fischer D, Teich A, Neubauer P, Hengge-Aronis R (1998) The general stress sigma factor $\sigma^{\mathrm{s}}$ of Escherichia coli is induced during diauxic shift from glucose to lactose. J Bacteriol 180: 6203-6206

Gallus C, Schink B (1998) Anaerobic degradation of $\alpha$-resorcylate by Thauera aromatica strain AR-1 proceeds via oxidation and decarboxylation to hydroxyhydroquinone. Arch Microbiol 169:333-338

Gallus C, Gorny N, Ludwig W, Schink B (1997) Anaerobic degradation of $\alpha$-resorcylate by a nitrate-reducing bacterium, Thauera aromatica strain AR-1. Syst Appl Microbiol 20:540-544

Harwood CS, Burchardt G, Herrmann H, Fuchs G (1999) Anaerobic metabolism of aromatic compounds via the benzoyl-CoA pathway. FEMS Microbiol Rev 22:439-458

Heider J, Fuchs G (1997) Anaerobic metabolism of aromatic compounds. Eur J Biochem 243:577-596

Heider J, Boll M, Breese K, Breinig S, Ebenau-Jehle C, Feil U, Gad'on N, Laempe D, Leuthner B, Mohamed M El-S, Schneider S, Burchard G, Fuchs G (1998) Differential induction of enzymes involved in anaerobic metabolism of aromatic compounds in the denitrifying bacterium Thauera aromatica. Arch Microbiol 170:120-131

Hueck CJ, Hillen W (1995) Catabolite repression in Bacillus subtilis: a global regulatory mechanism for gram-positive bacteria. Mol Microbiol 15:395-401

Laemmli UK (1970) Cleavage of structural proteins during assembly of the head of bacteriophage T4. Nature 227:680-685

Philipp B (1999) Neuartige oxidative Reaktionen beim anaeroben Abbau phenolischer Verbindungen durch denitrifizierende Bakterien. PhD Thesis, University of Konstanz

Philipp B, Schink B (1998) Evidence of two oxidative reaction steps initiating anaerobic degradation of resorcinol (1,3-dihydroxybenzene) by the denitrifying bacterium Azoarcus anaerobius. J Bacteriol 180:3644-3649

Postma PW, Lengeler JW, Jacobson GR (1993) Phosphoenolpyruvate:carbohydrate phosphotransferase systems of bacteria. Microbiol Rev 57:543-594

Schink B, Philipp B, Müller J (1999) Anaerobic degradation of phenolic compounds. Naturwissenschaften (in press)

Tschech A, Pfennig N (1984) Growth yield increase linked to caffeate reduction in Acetobacterium woodii. Arch Microbiol 134: 163-167

Widdel F, Pfennig N (1981) Studies on dissimilatory sulfate-reducing bacteria that decompose fatty acids I. Isolation of new sulfate-reducing bacteria enriched with acetate from saline environments. Description of Desulfobacter postgatei gen. nov. sp. nov. Arch Microbiol 129:395-400

Widdel F, Kohring GW, Mayer F (1983) Studies on dissimilatory sulfate-reducing bacteria that decompose fatty acids III. Characterization of the filamentous gliding Desulfonema limicola gen. nov. sp. nov., and Desulfonema magnum sp. nov. Arch Microbiol 134:286-294 